This item was submitted to Loughborough's Research Repository by the author.

Items in Figshare are protected by copyright, with all rights reserved, unless otherwise indicated.

\title{
William Morris and the problem of Englishness
}

PLEASE CITE THE PUBLISHED VERSION

PUBLISHER

(c) Sage

LICENCE

CC BY-NC-ND 4.0

REPOSITORY RECORD

Kinna, Ruth. 2019. "William Morris and the Problem of Englishness". figshare. https://hdl.handle.net/2134/715. 
This item was submitted to Loughborough's Institutional Repository by the author and is made available under the following Creative Commons Licence conditions.

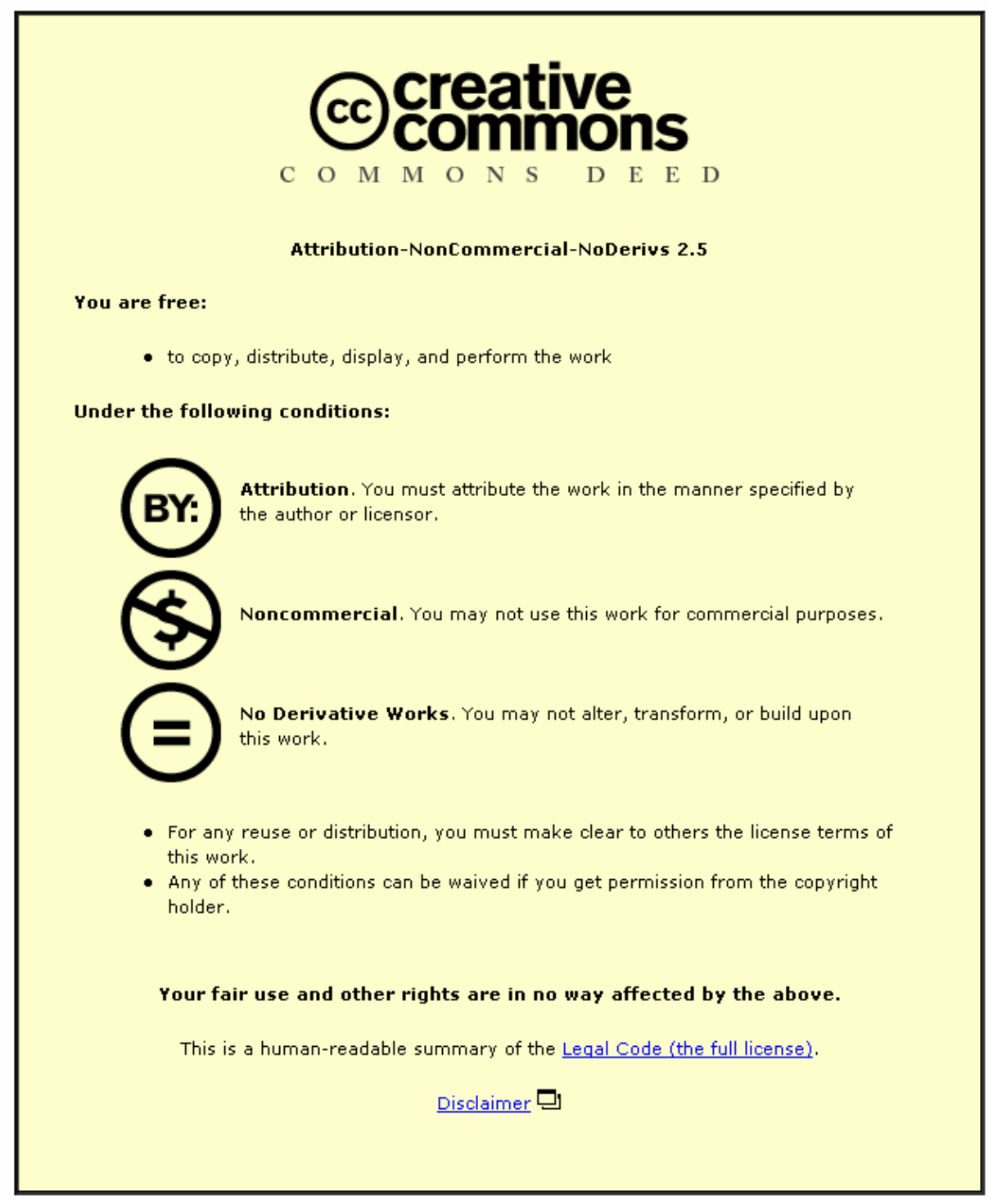

For the full text of this licence, please go to: http://creativecommons.org/licenses/by-nc-nd/2.5/ 


\section{든oughborough University}

This article has been submitted to Loughborough University's Institutional Repository by the author.

William Morris \& the Problem of Englishness ${ }^{1}$ - Dr. Ruth Kinna

In The Lion and the Unicorn George Orwell suggested that English socialists had underestimated the unifying role of patriotism in the struggle for socialist change. Marxists in particular, seduced by ideas of class struggle, had mistakenly associated socialism with soulless internationalism. ${ }^{2}$ Considering how eager late nineteenth century socialists - and Marxists - were to wrap their ideas in patriotic garb, Orwell's view appears dubious. Yet the idea that English socialists have neglected the importance of patriotism has proved to be persuasive: in recent years early socialists, including William Morris, the subject of this paper, have again been accused of wrongly overlooking the importance of national tradition to socialism. Whilst historians have acknowledged the force of his 'oppositional Englishness', ${ }^{3}$ political theorists notably David Miller - have argued that Morris opted for a sub-national form of community, based on fellowship, as the preferred unit of socialist organisation. $^{4}$

David Miller has dubbed Morris's idea of fellowship a concept of radical communitarianism which demands the formation of a limitless number of faceto-face communities. This ideal, he suggests, is unworkable and potentially 
illiberal. In fellowship, communities will either be so exclusive that socialists will be unable to pursue internationalist goals, or so inclusive that the social bonds necessary for co-operation will become hopelessly diluted. In the first case, fellowship encourages outmoded forms of organisation and in the second it fails to provide a sufficiently robust ground for social cohesion. ${ }^{5}$ Modern socialists, Miller suggests, should not give up on the idea of community, but should take heed of Orwell's advice, capitalise on national identity as a progressive, integrative force for socialist change and use the nation as the basis for community.

Morris undoubtedly lends himself to such criticism because of the way in which his thought has so readily been domesticated by his art into a prettified, romantic tradition. When his critical understanding of the construction of tradition is overlooked, his work is all too easily accommodated to that "warm" ... cosy and comfortable place' that community describes. ${ }^{6}$ Indeed, he might be considered another victim (along with Mill) of what Stephan Collini has called an 'English Heritage model' of the national past. $^{7}$ In an effort to rescue Morris, I argue that he promoted fellowship primarily because he believed that it was necessary to secure individual happiness in work, not because he wanted to stimulate a sense of sympathy through face-to-face association. Fellowship was to extend internationally, yet Morris tried to show that it was consistent with a national principle. The paper begins with an examination of Morris's idea of Englishness and considers the distinction he drew between this idea and the sense of belonging that formed the basis of patriotism or nationality in the state. I then consider Morris's concept of fellowship as a model of community. Finally I show how Morris 
linked his idea of fellowship to a constitutional arrangement that he believed to be quintessentially English. The thrust of Morris's argument is that the revival of English government will restore to the English their love of liberty and justice, providing a foundation for life in fellowship.

\section{Socialism and Englishness}

Nineteenth century socialists used the idea of England in a number of different ways. For example, H. M. Hyndman argued that the 'Anglo-Saxon race' had a particular genius for socialism. ${ }^{8}$ Robert Blatchford described Merrie England as a source of national strength and pride. ${ }^{9}$ Taking his lead from Walden rather than Merrie England Edward Carpenter described England as a place of falsehood and corruption but argued for an 'awakening of the National Conscience' and associated the 're-birth' of England with universal concepts of justice and honesty. ${ }^{10}$

Morris had little to say about any of these visions: though he judged Hyndman 'a jingo' ${ }^{11}$ His image of Englishness was shaped by a romantic attachment to the countryside, forged in boyhood through his knowledge of the landscape and the study of its history. ${ }^{12}$ Morris gave little indication that his affection for England had any political force until 1876 when, stirred by Turkish atrocities in Bulgaria and ensuing Russian actions, he assumed a prominent role in the Eastern Question Association (EQA). At this juncture, it became clear that Morris linked Englishness - a little like Carpenter - with a set of moral values.

In the EQA Morris situated himself against Disraeli's anti-Russian, proTurk position. His stance was influenced by his belief that a war on Turkey's 
behalf would jeopardise English justice. The English were 'at heart a generous people'. To contemplate going to war for a 'gang of thieves and murderers' was to betray their love of liberty and fairness. ${ }^{13}$ Whether it ended in victory or defeat, war would bring shame to England. Perhaps as a riposte to the jingo song of 1878 which boasted that 'we've got the men, we've got the ships, we've got the money, too', Morris's penned London Lads, a song which appealed to the English workers to remain true to their glorious past:

Wake, London Lads, wake, bold and free!

Arise, and fall to work, Lest England's glory come to be Bond-servant to the Turk! Think of your Sires! How oft and oft On freedom's field they bled, When Cromwell's hand was raised aloft, And Kings and scoundrels fled. ${ }^{14}$

The failure of Morris's appeal undercut his faith in the constancy of the national character and deepened his conception of Englishness. By April 1878 Morris was resigned to the idea that England would be 'for some years to come' a 'reactionary and Tory Nation'. ${ }^{15}$ War fever, he noted sourly, was 'raging in England, \& people go about in a Rule Britannia style that turns one's stomach ... ' 16 Englishness, Morris concluded, did not describe a static set of virtues, but was open to manipulation.

Morris's sense that England had been corrupted was reinforced in the early years of his involvement in Society for the Protection of Ancient Buildings, (Anti-Scrape) - a society Morris founded in 1877 in order to campaign against the restoration of medieval buildings. In Anti-Scrape, Morris contrasted medieval and modern methods of production to argue that the art of the Middle Ages reflected a particular way of life. This way of life, he 
suggested, had been destroyed and, whilst it was possible to protect its legacy, the possibility of continuing its art had been lost. ${ }^{17}$ On this view, restoration threatened more than the nation's architectural heritage, it threatened to wipe away the memory of the Middle Ages and the ideals that had inspired its artists. ${ }^{18}$ Morris fought hard to preserve the historical record but believed that in time the tangible evidence of England's real history would be lost, leaving little to temper the aggressive sense of nationhood that had been stimulated by Disraeli.

After 1883, when Morris declared for socialism, his critique of the corruption of Englishness hardened. Now he placed commerce or capitalism at the heart of England's ills. For example, in 1878 he had complained that the repair of St. Alban's Abbey would lead to wholesale modernization. ${ }^{19}$ Nine years later he argued that the 'money-bag' who backed the project had effectively removed all reminders of the 'that outburst of Mediaeval Communism', the Peasants' Revolt. ${ }^{20}$ Similarly, where Morris had previously bemoaned the filth and ugliness of industrialisation, as a socialist he blamed property developers for the destruction of the landscape and its history. In Under the Elm-Tree, Morris mused, 'if we must still be slaves and slaveholders, [the country-side] will not last long; the Battle of Ashdown will be forgotten for the last commercial crisis; Alfred's heraldry will yield to the lions of the half crown'.21

In addition, Morris broadened the basis of his critique by considering the relationship between nationhood and capitalism. Nations, he argued, first developed to 'afford mutual protection to their members'. Under capitalism, however, the nation had become a cover for the 'organised robbery of the 
weak both within and without [its] own bounds'. ${ }^{22}$ Though established European powers 'courted and flattered' new nations - Italy, for example - and treated their emergence as a sign of emancipation and progress, Morris insisted that in current conditions nationhood would do little to improve the lives of workers and peasants. In Italy, the 'bourgeois patriot' had succeeded in 'driving out the Germans [sic.]', but 'national vanity' did not confer on workers the right to form trade unions. ${ }^{23}$

In the international sphere, too, nationhood implied division. Capitalism, he argued, encouraged 'national competition' and was a cause of instability and conflict. $^{24}$ Nationhood habitually encouraged citizens to support the exploitation of foreigners and fostered the suspicion and fear necessary to support armed aggression. The ambition 'of "patriots" of all countries' was 'one group of workmen thriving somewhat at the expense of another'. ${ }^{25}$

Morris's analysis led him to conclude that internationalism offered the best solution to the problem of Englishness. Workers, he argued, would search in vain for an answer to exploitation from within the boundaries of the nation because they were all victims of 'commercial patriotism'. ${ }^{26}$ If they wanted to put a stop to capitalist oppression, they would have to bury their national differences and join hands with comrades across the globe. Socialists were 'internationalists not nationalists'. Yet in developing this stance, Morris did not loose sight of his earlier English ideal. Indeed, his internationalism supported national aspirations, when those aspirations were directed towards the realisation of universal ideals. So, socialists supported the Highland Crofters and the Irish against the English, the Soudanese, William Wallace, Garibaldi - any 'representative of ... countrymen in ... heroic 
defence of their liberties'. ${ }^{27}$ As internationalists, they also defended ancient English principles.

Morris outlined these principles by distinguishing more clearly between two competing national models. The first had a genuine pedigree and history and achieved its perfect expression in the Middle Ages. The second was artificial and had been recently constructed to suit the interests of the capitalist class. The goodness of the first was measured by the 'rank stupidity' and 'malicious scoundrelism' of the second. ${ }^{28}$ Old England had been characterised by independence and public duty. In the 'rough days of our forefathers', Morris argued, the law had its shortcomings, but it was never used to allow 'persons in authority by reason of their authority' to free themselves 'from the responsibilities of citizenship'. ${ }^{29}$ In contrast, Victorian England was held up as a model of 'order, peace, and stability ... common sense and practicality', but was defined by servility, ugliness and ostentatious display. ${ }^{30}$ The difference was apparent in every public institution. The old monarchy, for example, had had 'definite duties'. Now the sovereign was an 'ornamental official'. ${ }^{31}$ In the care of our 'stout ancestors' the jury-system had been animated by principles of truth-seeking and fair adjudication. In the modern world it was merely a cover for the routine conviction of criminals. ${ }^{32}$ Sycophancy was now the watchword of England and the transformation of Westminster Abbey from a place of study and reflection into a "National Valhalla"' was symptomatic of its style. ${ }^{33}$

Morris acknowledged that it was sometimes difficult to distinguish between old and new England because the capitalist class had successfully used the values and symbols old England to legitimise their rule. The 
'hypocrisy of so-called constitutional development' Morris argued, 'has blinded us to the greatness of the change which has taken place; we use the words King, Parliament, Commerce, and so on, as if their connotation was the same as in that past time'. ${ }^{34}$ In an effort to expose the fraud, Morris sometimes tried a similar tack, recasting new principles to highlight the dishonesty of the system they were designed to support. ${ }^{35}$ But he raised his strongest defence of Englishness by insisting on the distinction and evoking the nation's glorious past. In Socialists At Play, Morris returned to the themes he first explored in London Lads, now tying Englishness to an international revolutionary tradition.

We must be men. You comrades, you who came In trust of England's ancient honoured name Unto this "home of freedom o'er the wave," "This loosener of the fetters of the slave," E'en here have felt the petty tyrant's will, Who robes and worries where he may not kill We must be men, or we shall find one day Our boasted safe asylum swept away ...

Lastly, we pray you, 'ere we part, to raise Your voices once more in the "Marseillaise," The glorious strain that long ago foretold The hope now multiplied a thousand-fold: Nay, hope transfigured; since at last we know The world our country; and the rich our foe ${ }^{36}$

Morris's socialist ideal, which he described as the 'true development of nations', required that "national life" in the sense in which we now use the words [will have]... come to an end'. ${ }^{37}$ His vision was not so different from Orwell's. Orwell argued that the Blitz had released a patriotic egalitarianism that would form the basis of a post-war social democracy. Morris argued that the looming capitalist crisis would unleash a workers movement directed towards the socialist reconstruction of England. There are, however, considerable differences: whereas Orwell defined social democracy in terms 
of nationalisation and social welfare, Morris defined it as fellowship.

Socialism \& Fellowship

Morris developed his idea of fellowship in the early 1850s when he was at Oxford. Under the influence of the Anglo-Catholic movement and then under the spell of the Pre-Raphaelites he banded together with his friends in 'The Brotherhood'. ${ }^{38}$ In his early literature he used fellowship to describe a narrowly fraternal or brotherly bond between men which, developed from conscious desire, was usually undermined by romance. He also invoked fellowship to develop a theory of action, linking fellowship with heroism or manliness in the pursuit of a better life. Fellowship embraced virtues such as the ability to embrace change, to do what necessity demanded and to act justly and courageously. ${ }^{39}$

In his socialist thought, Morris continued to associate fellowship with manly action. ${ }^{40}$ But, in contrast to his earlier treatment, he defined fellowship as the abolition of slavery, by which he meant any social relation that was not entered into freely: labour and marriage were the two most important examples modern society. The effect of this definition was to make fellowship fully compatible with romantic love and to extend it to women. Fellowship described a condition in which all labour was voluntary and marriage was abolished in favour of free love.

Morris also suggested that fellowship had an ethical and a material aspect. He traced the roots of the ethical idea to the Middle Ages, crediting the leaders of the Peasants' Revolt and, in the Tudor period, Sir Thomas More, with its development. Nevertheless, Morris argued that fellowship could 
only succeed in socialism when class differences, poverty and the inequalities that bred dependency were eradicated. Once this material base was secured, fellowship would promote mutual support and co-operation - in Morris's terms, 'an ethical or religious sense of the responsibility of each man to each and for all his fellows'. ${ }^{41}$

In what sense is fellowship a model of community? Certainly, Morris believed the two were closely connected and often used the terms interchangeably. What he meant by these terms can be gauged by comparing his notion of fellowship with three well-known models of community developed by Ferdinand Tönnies, Raymond Plant and Andrew Reeve.

Like Tönnies Morris used fellowship to describe the transition from the medieval to the modern world, as well as a type of social system. He also suggested that this process of modernisation signalled a qualitative change in social relationships. Tönnies described this change by distinguishing between the natural will of community, where social action was deliberate and expressive, and the rational will of association, where it was accidental and instrumental. ${ }^{42} \mathrm{He}$ illustrated this overarching distinction in a number of ways, for example, in contrast between the friendship of community and the calculation of association. ${ }^{43}$ Morris lacked Tönnies' sociological detachment but he expressed a similar idea in the contrast he drew between fellowship and slavery, or mastership, as he sometimes labelled it. ${ }^{44}$ In slavery, individuals were atomised, their relationships were impersonal and, above all, regulated by contract. In News From Nowhere, Morris's heroine Ellen suggests that mastership 'was founded on lies and false pretensions'. ${ }^{45}$ By 
contrast, fellowship encouraged sympathy based on simplicity, truthfulness and honesty. In The Dream of John Ball Morris argued:

he that waketh in hell and feeleth his heart fail him, shall have memory of the merry days of earth, and how that when his heart failed him there, he cried on his fellow, were it his wife or his son or his brother ... and how that his fellow heard him and came ... This shall he think on in hell, and cry on his fellow to help him, and shall find that therein is no help because there is not fellowship, but every man for himself. Therefore, I tell you that the proud, despiteous rich man, though he knoweth it not, is in hell already, because he hath no fellow. ${ }^{46}$

As a social system, Morris's idea of fellowship fits neatly into Raymond Plant's model of left communitarianism. In Plant's typology left communitarianism is defined by its commitment to equality and autonomy. It is distinguished from right communitarianism in its rejection of hierarchy and tradition and from liberal communitarianism in the value it places on the subjective sense of belonging. ${ }^{47}$ Fellowship shares all these features. Morris defended it as an egalitarian ideal because it demanded the realisation of the common ownership of the means of production. He also defended the principle of autonomy in fellowship, above all in the context of work where drawing on his work in Anti-Scrape - he proposed a return to medieval methods of production. In Morris's view, history demonstrated that in the craft guilds 'mastership, in our sense of the word, was unknown'. ${ }^{8}$ All craft workers, apprentices and journeymen alike, had been encouraged to express themselves creatively. Even though they 'moved in a narrow circle', all were equally free to develop their talents. ${ }^{49}$ In fellowship they would enjoy the same latitude. Unlike the 'wretched lop-sided creatures' forced to labour in capitalism, they would be free from the 'excess of the division of labour' and be able to take a direct interest in the artefacts they produced. ${ }^{50}$

Morris used the same example to show how fellowship would encourage 
co-operation and stimulate the subjective sense of belonging which Plant identifies with left communitarianism. ${ }^{51}$ The craft guilds, he argued, were associations of 'hearty goodwill' between 'friends and good fellows'. ${ }^{2}$ The 'aspirations of the time', Morris argued, promised 'fulfilment, \& ... were definitely social in character'. ${ }^{53}$ Though capitalism permitted workers to organise in solidarity with others - notably in trade unions - it inhibited the development of the sense of purpose and feeling of unity that characterised fellowship. As Morris explained:

There must be no contention of man with man, but association instead; so only can labour be ... harmoniously organized. But harmony cannot co-exist with contention for individual gain: men must work for the common gain if the world is to be raised out of its present misery; therefore that claim of the workman ... must be subject to the fact that he is but a part of a harmonious whole: he is worthless without the cooperation of his fellows, who help him according to their capacities: he ought to feel, and will feel when he has his right senses, that he is working for his own interest when he is working for that of the community. ${ }^{54}$

Finally, Morris's idea of fellowship was posited on a sense of loss that Andrew Reeve places at the heart of community. Drawing back to Tönnies' model of community in an attempt to refine Plant's typology, Reeve argues that community is best treated as a concept informed by absence and the 'perception that industrial society possessed novel features' ${ }^{55}$ The loss of community might be expressed in different ways, and Reeve rightly identifies Morris as an exponent of community that rests upon a 'shared commitment to worthwhile work in a world that had been aesthetically renewed' ${ }^{56}$ Morris regretted the disappearance of those conditions that had enabled craftsmen to enjoy their labour. In his view, this was the most significant loss that socialism would repair. As Hammond tells Guest in News From Nowhere, the crucial difference between the old and the post-revolutionary world - the one 
that underpinned all the rest - was the transformation of work into 'sensuous pleasure'. $^{57}$

Placed alongside the frameworks developed by Tönnies and Plant, fellowship appears not only appears to be a model of community, but an example of radical communitarianism, exhibiting many of the weaknesses that critics have pointed to. As Caroline McCulloch suggests, Morris believed that fellowship described a set of behaviours and hoped that it would be extended to all once social equality and classlessness were realised. At the same time, he also considered fellowship as a social system and argued that it would generate co-operation and encourage individuals to recognise that their social well-being is connected to that of the group. ${ }^{58}$ His desire for fellowship appears to pull him in two different directions at once: towards diffuse, international unity on the one hand and small, exclusive association on the other.

Yet the difficulty of reconciling the universal aspect of fellowship with the particular element is exaggerated by the false assumption that Morris framed fellowship with a view to bringing individuals into face-to-face contact; an assumption based on a reading of fellowship that misjudges Morris's love of medievalism and the value he attached to the craft guilds. If, following the insights offered by Reeve's model of community, fellowship is treated as a concept predicated on loss, the nature of this misjudgement becomes clear. Unlike Tönnies, who also considered the loss of community as the loss of labour as art, Morris defined the loss of fellowship as a loss of pleasure, not of friendship. $^{59}$ Indeed, Morris was well aware that organisations like the craft guilds raised serious problems for inter-group communality. ${ }^{60}$ And whilst he 
hoped that solidarity would develop through fellowship, he argued that cooperation was underwritten by the satisfaction of individual desires. No matter how closely they associated with one another, fellowship would only flourish when individuals were again made happy in their daily work.

Fellowship, then, was a broad and inclusive concept and its social bonds could be quite loose. Morris undoubtedly preferred to live in close contact with others, but he did not expect others to share this preference or generalise it into a socialist principle. ${ }^{61}$ In News From Nowhere individuals enjoy an unrestricted choice of living in densely or sparsely populated areas, in private or in shared houses. ${ }^{62}$ Moreover, whilst his heroine Ellen professes a desire to settle permanently in one place, individuals move about from one settlement to another. Social relations are conducted with affectionate civility and individuals call each other 'friend' or 'neighbour'. But these terms are used as salutations, not epithets. And though romance is still based on an idea of uniqueness, friendships succeed indiscriminately. Indeed, some commentators have suggested that Morris's communities are 'mere shells'. ${ }^{63}$

Morris realised that his socialist ideal required a source of social cohesion. In 1889 he argued that communist society would unravel in the absence of shared commitments. Drawing his critique of the state together with his idea of fellowship, he found this commitment in an idea of selfgovernment linked to nationality.

\section{Fellowship and Englishness}

Morris developed the relationship between fellowship and the principle of selfgovernment in a reading of history which identified 'true' Englishness with the 
development of liberty through the constitution. Returning to the themes he first explored in the EQA, he argued that the English had a natural bent towards liberty, rather as Hyndman suggested. But unlike Hyndman Morris insisted that the restoration of the English constitution required revolution. ${ }^{64}$ In Morris's constitutional history, the rise of the capitalist state had resulted in the imposition of an artificial system of government. This had to be destroyed. Following the lead of the Oxford historians - E.A. Freeman, J.R. Green and William Stubbs - Morris identified the English constitution with ancient principles and not with particular documents or laws. ${ }^{65}$ He described these principles as 'federalism', distinguishing them from 'bureaucracy'.

Federalism sprang from a loose form of tribal association where groups had joined with each other in order to provide for their mutual needs. At first, these tribes had been federated under a single chief, but by the tenth century, federalism had assumed a feudal character and the tribal chief had become a king, 'the master of the land giving fiefs to his earls and thanes, who in their turn gave them to their free men'. ${ }^{66}$ In both manifestations, however, the principle of federalism was the same: "No rights without duties, no duties without rights"'. 67 Bureaucracy expressed no such reciprocity. Pioneered in Rome, bureaucracy was a hierarchical principle based on the strict adherence to formal law and directed towards 'tax-gathering'. ${ }^{68}$ Between 1066 and 1377, federalism and bureaucracy were fundamentally transformed. Federalism became an anti-feudal movement, taking root in the city-states at the point when the craft guilds began to dominate medieval life. In this guise, federalism continued to give expression to an idea of reciprocal rights and duties but it was now an urban idea and it was linked to a demand for local 
decision-making control. Bureaucracy, too, shed its feudal aspect, having been revived from a period of stagnation by the rise of mercantilism and the increasing centralisation of political power. Federalism and bureaucracy remained at loggerheads, but as a result of this transformation the battle between the two principles was not fought between different ethnic groups within particular territories, but between artisans and elites across Europe. It was a battle for self-government against the organisation of the state. ${ }^{69}$ By the fifteenth century, the state principle had gained the advantage. All over Europe, Morris noted, 'the modern political bureaucratic nation was being developed'. ${ }^{70}$

Morris established the Englishness of the federal principle and the alien character of bureaucracy by examining the different cultural impact of the two phenomena. Federalism, he argued, was established in England in the course of the fifth and sixth centuries during recurrent waves of Teutonic invasion. Until the beginning of the eleventh century the native 'Britons' resisted these assaults fiercely. Yet for all the bloodshed, Morris found that in 'manners and language' the natives and their Germanic conquerors were essentially the same. Indeed, the two groups were 'so much alike, that, the fighting once over, the social condition of the people was little altered'. ${ }^{71}$ Bureaucracy, by contrast, was first introduced in the Roman period, to be reintroduced in 1066 with the Norman Conquest. With its reintroduction the nation was disasterously 'Frenchified'. The process was most apparent in the language. Even before his turn to socialism, Morris had bemoaned the introduction of 'beastly' French words into English. ${ }^{72}$ At the height of his socialist career, he repeated these complaints, extending the notion of the 
'Norman yoke' to describe the degradation of English life. What now passed under the name of English was in fact 'a dialect of Latin', 'a wretched mongrel jargon that can scarcely be called English, or indeed language'. ${ }^{73}$ Literature, too, had been 'Frenchified'. ${ }^{74}$ So great was the corruption, that nineteenth century professors wrongly traced the evolution of English literature from Shakespeare, instead of Beowulf. ${ }^{75}$

Englishness was important to the federal principle because Morris wanted to argue, very much like Orwell, that socialism resonated with the national character. Yet whilst Englishness apparently had a strong ethnic root, Morris did not consider the revival of the English constitution as an assertion of racial superiority. Even whilst lamenting the importation of foreign words into the language, he insisted that England was a melting pot and that its strengths were derived from 'contributions from so many races assimilated at so many periods'. ${ }^{76}$ The history of federalism suggested that the cure for bureaucratic excess would be found in class struggle, not race war: 'masters and middle-men are of the same blood as the men; it is their position ... which turns good fellows into tyrants \& cheats'. ${ }^{77}$ In the modern world, the choice between federalism and bureaucracy was a choice between 'the Community' on the one hand, and 'the State or the Government' on the other. Socialists could either 'have a Community master of itself, or a Government master of the Community, as at present'. ${ }^{78}$

As the constitutional principle of community, federalism required the decentralisation of power to the township, or the parish, or the ward, or local guild' so that each body could 'manage its own affairs'. ${ }^{79}$ It replicated in the political realm the social relations that Morris associated with fellowship in the 
economic sphere. For example, federalism encouraged 'the freedom and cultivation of the individual will'. In self-government individuals would shake off 'the slavish dependence ... on artificial systems made to save men manly trouble and responsibility'. ${ }^{80}$ And whilst freedom would breed variety and difference - in landscape, building, diet, amusements and costume ${ }^{81}$ - active participation would foster trust and help build solidarity. ${ }^{82}$

In Morris's view, such a system would serve as a ground for the new expression of Englishness. Federalism was a principle of voluntary association and socialists would federate 'as convenience of place, climate, language \&c., dictated'. ${ }^{83}$ But it would not be forged arbitrarily. It had 'a geographical or ethnological expression' and it encouraged association amongst those who felt bound by culture, language or history, enabling previously oppressed groups, like the English, to creatively express these bonds.

Anticipating that local communes would wish 'to federate for national or international purposes', ${ }^{84}$ Morris suggested that relations between federal bodies would be regulated by broad principles of association. Although the administration of local affairs would be conducted in small communal assemblies, a 'central body whose function would be ... the guardianship of the principles of society' would mediate between groups in cases of dispute and protect all individuals against tyranny. ${ }^{85}$ Morris's historical narrative suggested that these principles were based on a system of reciprocal rights and duties. His understanding of fellowship pointed to an alternative rendering of the same idea: that socialist federation embrace a commitment 
against slavery. This was the interpretation Morris offered in Socialism From the Root Up:

It is clear that in such a society what laws were needed for the protection of persons and the regulation of inter-communal disputes ... would have to be universal, and the central regulating body would be charged with their guardianship, and at a last resort to carrying them out by force. Obviously no community could be allowed to revert to the exploitation of labour of any kind under whatever pretext, or to such forms of reaction as vindictive criminal laws. Such measures if allowed ... would undermine the very foundations of communistic society. The unity in Federation in short, appears to be the only method for reducing complexity political and administrative matters to a minimum; and of ensuring to the individual, as a unit of society, the utmost possible freedom for the satisfaction and development of his capacities. ${ }^{86}$

These principles of socialist federation help to explain both why and how Morris expected individual desires in post-revolutionary society would adapt spontaneously to fit social goals when those goals were defined by communities made up of strangers. Whilst fellowship was posited on an idea of self-expression and artistic creativity, federalism tied art inextricably to culture. Morris's reading of English history suggested that to fulfil oneself through art was to participate in the creation or re-creation of national culture. Indeed, his expectation that individuals would federate in national groups implied that artists could not easily detach themselves from the cultural environment in which they were raised: to express artistic freedom in federation was, at the same time, to give expression to a set of common values.

\section{Conclusion}

The starting point for this paper was the suggestion that Morris had wrongly underestimated the importance of nationality to socialism and as a result had 
advanced a vision of socialist organisation that is both unworkable and undesirable. I have argued that Morris considered the struggle for socialism to be international struggle and that it would lead to a genuine sense of nationhood. As Morris's critics suggest, his idea of socialist fellowship can be described as communitarian, but they have failed to note that Morris argued that the motivation for socialism was enjoyable labour and not, as claimed, friendship, solidarity or the love of humanity. Fellowship was linked to a theory of organisation but, contrary to the critics, it did not uniformly demand small-scale organisation in order to work. As a result, Morris did not face the problem of reconciling individual self-expression with community as it has been outlined. Admittedly, Morris's desire to recreate a rural utopia on the basis of an individualistic concept of desire is problematic and remains difficult to see how or why individuals should spontaneously want to express themselves through Morris's aesthetic. Nonetheless, his understanding that fellowship was rooted in enjoyable labour demonstrates that he had a strong formal commitment to individuality and creative self-expression.

Finally, as a communitarian, Morris did not suppose that nationality was a sufficient guarantee of harmonious communal or inter-communal relations. Communes within a particular nation might be expected to sympathise with each other and, for example, provide aid in times of need, but Morris supported fellowship with a constitutional arrangement which was backed by the moral imperative to guarantee all individuals the same opportunities for enjoyable labour. The principle of federation reinforced the idea that the solidarity generated by fellowship could be quite weak: as Orwell realised, war generated a much stronger sense of belonging. But fellowship 
was designed to enable individuals to cohere in national grouping without sacrificing the idea of a common humanity. Whilst there is a tension between Morris's class and ethnic understanding of federalism, his model has two distinct advantages over Orwell's: it promised to provide a more stable and lasting base for socialist reform than war, and one that was less likely to degenerate into jingoism. Hyndman and Blatchford both demonstrated the ease with which socialists could loose sight of internationalist goals. Morris met this danger by attempting to build a national idea that was separate from the state. In doing so he tried to ensure that the notion of a common home was closed off from manipulation.

Bibliography

Bevir, Mark (1998) 'William Morris: The Modern Self, Art, and Politics', History of European Ideas 24:175-94.

Bauman, Zygmunt (2001) Community: Seeking Safety in an Insecure World. Oxford: Polity.

Blatchford, Robert (1977) Merrie England. London: Journeyman Press.

Collini, Stefan 'From Dangerous Partisan to National Possession: John Stuart Mill in English Culture 1873-1933' in Collini (1994) Public Moralists: Political Thought and Intellectual Life in Britain, Oxford: Clarendon Press pp311-42.

Hyndman, H.M. (1973) England For All. Susses: The Harvester Press.

Carpenter, Edward (1919) England's Ideal. London: George, Allen \& Unwin. 
Davis, Laurence 'Morris, Wilde, and Marx on the Social Preconditions of Individual Development', Political Studies 44:719-732.

Faulkner, Peter (1992) William Morris and the Idea of England. London: William Morris Society.

Ingle, Stephen (2002) Narratives of British Socialism. Basingstoke: Palgrave/Macmillan.

Jones, H.S. (2000) Victorian Political Thought. Basingstoke: Macmillan.

Kinna, Ruth (2000) William Morris: The Art of Socialism. Cardiff: University of Wales Press.

McCulloch, Caroline 'The Problem of Fellowship in Communitarian Theory: William Morris and Peter Kropotkin' Political Studies 32:437-50.

Mackail, J.W. (1912) The Life of William Morris vol.1. London: Longmans, Green and Co. Miller.

Miller, David (1989) Market, State and Community: Theoretical Foundations of Market Socialism. Oxford: Clarendon Press.

Miller, David (2000)'Communitarianism: Left, Right and Centre’, Citizenship and National Identity. Oxford: Polity Press.

Morris, William (1992) The Collected Works of William Morris vol. XVI. London:Routledge/Thoemmes Press.

Morris, William (1992) The Collected Works of William Morris vol. XXII. London: Routledge/Thoemmes Press.

Morris, William (1992) The Collected Works of William Morris vol. XXIII. London: Routledge/Thoemmes Press.

Morris, William (1969) The Unpublished Lectures of William Morris Eugene D. LeMire (ed). Detroit: Wayne State University Press 
Morris, William (1984) The Collected Letters of William Morris, Norman Kelvin (ed) vol.1. New Jersey: Princeton University Press.

Morris, William (1987) The Collected Letters of William Morris, Norman Kelvin (ed) vol. 2. New Jersey: Princeton University Press.

Morris, William (1994) Political Writings: Contributions to Justice and Commonweal 1883-1890 Nicholas Salmon (ed). Bristol:Thoemmes Press.

Morris, William (1996) Journalism: Contributions to Commonweal 1885-1890 Nicholas Salmon (ed). Bristol:Thoemmes Press.

Nisbet, R.A. (1980) The Sociological Tradition. London: Heinemann.

Plant, Raymond (1978) 'Community: Concept, Conception and Ideology' Politics \& Society 8:79-107.

Orwell, George (1982) The Lion and the Unicorn, Harmondsworth: Penguin.

Reeve, Andrew 'Community, Industrial Society, and Contemporary Debate' in Iain Hampsher-Monk and Jeffrey Stanyer (eds) (1996) Contemporary Political Studies vol.2 pp1083-92.

Synowich, Christine 'William Morris's Egalitarian Perfectionism', Journal of the William Morris Society XII:12-20.

Yeo, Stephen, 'Oppositional Englishness', in R. Colls \& P. Dodd (eds) Englishness: Politics and Culture 1880-1910 pp. 308-69. 
${ }^{1}$ I'd like to thank Vincent Geoghegan for comments on an earlier draft of this paper.

${ }^{2}$ George Orwell (1982) The Lion and the Unicorn. Harmondsworth: Penguin.

${ }^{3}$ Stephen Yeo, 'Oppositional Englishness' in R.Colls and P.Dodd (eds) (1986) Englishness: Politics and Culture 1880-1910, pp308-69. London: Croom Helm.

${ }^{4}$ David Miller, (1989) Market, State and Community: Theoretical Foundations of Market Socialism. Oxford: Clarendon Press pp227-33; 'Communitarianism: Left, Right and Centre’, in Miller (2000) Citizenship and National Identity. Oxford: Polity Press.

${ }^{5}$ Miller draws on Caroline McCulloch (1984) 'The Problem of Fellowship in Communitarian Theory: William Morris and Peter Kropotkin', Political Studies 32:437-50. For a discussion of Morris's communitarianism see Laurence Davis (1996) 'Morris, Wilde, and Marx on the Social Preconditions of Individual Development', Political Studies, 44:719-32 and Christine Sypnowich (1999) 'William Morris's Egalitarian Perfectionism', The Journal of the William Morris Society XIII:12-21

${ }^{6}$ Zygmunt Bauman (2001) Community: Seeking Safety in an Insecure World p1. A version of this image of Morris is presented by Mark Bevir (1998) 'William Morris: The Modern Self, Art, and Politics', History of European Ideas 24:177

${ }^{7}$ Stefan Collini, 'From Dangerous Partisan to National Possession: John Stuart Mill in English Culture 1873-1933' in Collini (1994) Public Moralists: Political Thought and Intellectual Life in Britain, p339. Oxford: Clarendon Press.

${ }^{8}$ H.M.Hyndman (1973) England For All. Sussex: The Harvester Press p168.

${ }^{9}$ Robert Blatchford (1977) Merrie England. London: The Journeyman Press p14.

${ }^{10}$ Edward Carpenter (1919) England's Ideal. London: George Allen \& Unwin pp14-17.

${ }^{11}$ William Morris in Norman Kelvin (ed) (1987) The Collected Letters of William Morris, vol. 2. New Jersey: Princeton University Press p369.

12 Peter Faulkner (1992) William Morris and the Idea of England. London: William Morris Society p5. 
${ }^{13}$ William Morris in Norman Kelvin (ed) (1984) The Collected Letters of William Morris vol.1 New Jersey: Princeton University Press p323.

${ }^{14}$ Morris 14 p436.

${ }^{15}$ Morris 14 p476.

${ }^{16}$ Morris 14 p446.

17 William Morris (1992) The Collected Works of William Morris vol. XXII. London: Routledge/Thoemmes Press p133.

${ }^{18}$ Morris 14 p508

${ }^{19}$ Morris 14 p495-6.

${ }^{20}$ William Morris (1996) in Nicholas Salmon (ed) Journalism: Contributions to Commonweal 1885-1890. Bristol: Thoemmes Press p261.

${ }^{21}$ William Morris (1994) in Nicholas Salmon (ed) Political Writings: Contributions to Justice and Commonweal 1883-1890. Bristol: Thoemmes Press p429.

${ }^{22}$ Morris 21 p668

${ }^{23}$ Morris 21 p666.

${ }^{24}$ Morris 21 p673.

${ }^{25}$ Morris 21 p240.

${ }^{26}$ Morris $21 \mathrm{p} 499$.

${ }^{27}$ Morris $11 \mathrm{p} 410$.

${ }^{28}$ Morris 21 p499.

${ }^{29}$ Morris 21 p333.

30 William Morris (1992) Collected Works of William Morris vol. XXIII. London: Routledge/Thoemmes Press p208.

${ }^{31}$ Morris 21 pp598-9.

${ }^{32}$ Morris 21 p487.

${ }^{33}$ Morris 18 p411

${ }^{34}$ Morris 18 p.379.

${ }^{35}$ Morris 21 p105.

${ }^{36}$ William Morris in May Morris (1966) William Morris: Artist, Writer, Socialist vol.2. New York: 
Russell \& Russell pp.625-6.

${ }^{37}$ Morris $21 \mathrm{p} 155$.

${ }^{38}$ J.W.Mackail (1912) The Life of William Morris vol.1. London: Longmans, Green and Co. pp63-9.

${ }^{39}$ Ruth Kinna (2000) William Morris: The Art of Socialism. Cardiff: University of Wales Press pp75-9.

40 William Morris (1992) The Collected Works of William Morris vol. XVI. London: Routledge/Thoemmes Press p53-6.

${ }^{41}$ Morris 11 p763

${ }^{42}$ R.A.Nisbet (1980) The Sociological Tradition. London: Heinemann pp74-5.

${ }^{43}$ Nisbet 47 pp76-7.

${ }^{44}$ Morris 31 p124.

${ }^{45}$ Morris 44 p386.

${ }^{46}$ Morris 44 p52.

${ }^{47}$ Raymond Plant 'Community: Concept, Conception and Ideology' Politics \& Society 8: 90107

${ }^{48}$ Morris 22 p504.

${ }^{49}$ Morris 18 p386.

${ }^{50}$ Morris 18 p346.

${ }^{51}$ Morris 18 pp335;338.

${ }^{52}$ William Morris in Eugene D. LeMire (ed) (1969) The Unpublished Lectures of William Morris. Detroit: Wayne State University Press.p91.

${ }^{53}$ Morris 18 p388.

${ }^{54}$ Morris 31 p133.

55 Andrew Reeve 'Community, Industrial Society, and Contemporary Debate' in lain Hampsher-Monk and Jeffrey Stanyer (eds) (1996) Contemporary Political Studies vol.2 pp1090;1092.

${ }^{56}$ Reeve 61 p1090

${ }^{57}$ Morris 44 p275. 
${ }^{58}$ McCulloch 4 p446.

${ }^{59}$ Nisbet 47 pp74;76.

${ }^{60}$ Morris 18 p388.

${ }^{61}$ Morris 31 p23.

${ }^{62}$ Morris 44 pp246-7;344.

${ }^{63}$ Stephen Ingle (2002) Narratives of British Socialism. Basingstoke: Palgrave/Macmillan p113.

${ }^{64}$ Hyndman 8 p194; Morris 31 pp208;212.

${ }^{65}$ H.S.Jones (2000) Victorian Political Thought. Basingstoke: Macmillan p52.

${ }^{66}$ Morris 57 p171.

${ }^{67}$ Morris 57 p164.

${ }^{68}$ Morris 57 pp39;161.

${ }^{69}$ Morris 57 p177.

${ }^{70}$ Morris 21 pp506-7.

${ }^{71}$ Morris 57 p173.

${ }^{72}$ Morris 14 pp344;381.

${ }^{73}$ Morris 31 p241.

${ }^{74}$ Morris 57 pp167;176-7.

${ }^{75}$ Morris 11 p589.

${ }^{76}$ Morris 21 p83.

${ }^{77}$ Morris 11 p485.

${ }^{78}$ Morris 11 p766.

${ }^{79}$ Morris 11 p770.

${ }^{80}$ Morris 40 p457.

${ }^{81}$ Morris 44 p268.

${ }^{82}$ Morris 11 p770.

${ }^{83}$ Morris 11 p763;770.

${ }^{84}$ Morris 57 pp230-1.

${ }^{85}$ Morris 11 p769. 
${ }^{86}$ Morris 21 pp612-3. 